\title{
Short communication: Supplementing lysine and methionine in a lactation diet containing a high concentration of wet corn gluten feed did not alter milk protein yield
}

\author{
C. R. Mullins, ${ }^{* 1}$ D. Weber,$\dagger^{2}$ E. Block, $\dagger$ J. F. Smith,,${ }^{* 3}$ M. J. Brouk, ${ }^{*}$ and B. J. Bradford ${ }^{* 4}$ \\ *Department of Animal Sciences and Industry, Kansas State University, Manhattan 66506 \\ †Arm \& Hammer Animal Nutrition, Princeton, NJ 08540
}

\section{ABSTRACT}

Primiparous $(\mathrm{n}=33)$ and multiparous $(\mathrm{n}=63)$ lactating Holstein cows $(186 \pm 51 \mathrm{~d}$ in milk) were used to evaluate the effects of supplementing metabolizable amino acids using lysine in a matrix of Ca salts of fatty acids (Megamine-L, Arm \& Hammer Animal Nutrition, Princeton, NJ) and the isopropyl ester of 2-hydroxy4-(methylthio) butanoic acid (MetaSmart, Adisseo Inc., Antony, France) in diets containing $>26 \%$ wet corn gluten feed (dry matter basis). Cows were blocked by production level, parity, and pregnancy status, then randomly assigned to 1 of 8 pens and allowed a $7-\mathrm{d}$ adaption period before receiving dietary treatments for $28 \mathrm{~d}$. Pens were assigned randomly to either of 2 diets formulated to differ by metabolizable amino acid supply. Dry matter intake and production were monitored daily and milk components analyzed $3 \mathrm{~d} /$ wk. Data were analyzed using mixed models with repeated measures. The original design of the study consisted of a control diet predicted to be deficient in lysine and methionine; however, after ingredient nutrients were analyzed and modeled with animal requirements at dry matter intake $[26.6 \pm 0.35 \mathrm{~kg} / \mathrm{d}($ mean $\pm \mathrm{SEM})]$ and milk production levels achieved during the study $(40.1 \pm 0.46 \mathrm{~kg} / \mathrm{d})$, only marginal deficiencies were predicted for the control $(-8.1 \mathrm{~g} / \mathrm{d}$ for lysine; $-1 \mathrm{~g} / \mathrm{d}$ for methionine) according to the National Research Council method, whereas the Cornell Net Carbohydrate and Protein System 5.0 and 6.1 models indicated positive balances for these amino acids $(25.9$ and $21.8 \mathrm{~g} / \mathrm{d}$ for lysine, 14.7 and $18.9 \mathrm{~g} / \mathrm{d}$ for methionine, respectively). Supplementing $30 \mathrm{~g} / \mathrm{d}$ of metabolizable lysine in a Ca soap matrix and $2.4 \mathrm{~g} / \mathrm{d}$ of metabolizable methionine as 2-hydroxy-4-(methylthio) butanoic acid led to positive predicted lysine and me-

Received March 5, 2013

Accepted May 1, 2013.

${ }^{1}$ Current address: GPS Dairy Consulting, Maryville, MO 64468.

${ }^{2}$ Current address: Thousand Hills Herd Services, Newton, KS 67114.

${ }^{3}$ Current address: Department of Animal Science, University of Arizona, Tucson 85721.

${ }^{4}$ Corresponding author: bbradfor@ksu.edu thionine balances by all 3 models, and predicted metabolizable lysine-to-methionine ratios ranging from 2.9 to 3.1. No treatment effects were observed for dry matter intake, milk yield, milk component concentrations or yields, or energy-corrected milk yield. Despite the negative lysine balance and low lysine-to-methionine ratio predicted by the National Research Council model, results provided no evidence of a lysine deficiency in the control diet.

Key words: dairy cattle, by-product, amino acid

\section{Short Communication}

Formulation of diets to meet the protein requirements of dairy cattle has evolved from a focus simply on $\mathrm{CP}$ to estimating MP supply, which attempts to account for ruminal protein degradation, microbial yield, and ruminal bypass protein. Formulating for MP has been shown to improve the efficiency of dietary nitrogen utilization (Leonardi et al., 2003; Noftsger and St Pierre, 2003; Chen et al., 2011), while possibly improving production (Schwab, 2010). However, formulating for an adequate MP supply may still fail to meet the requirements of the cow if AA profile is not considered. This concept has been widely recognized by the US dairy industry; a survey conducted in 2010 indicated that $81 \%$ of nutritionists and veterinarians formulate diets to balance for AA (Dairy Herd Network, 2010). Enhanced knowledge of protein nutrition has been directly responsible for this progression; still, the cost of protein sources, combined with environmental stewardship, demand even more efficient use of dietary protein.

By-products from corn biofuel production are often used to provide protein and energy in lactation diets. In 2010, of the nutritionists and veterinarians who formulate rations and completed the survey, $92 \%$ used distillers grains or considered using them (Dairy Herd Network, 2010). Many other by-products of corn milling are also fed to dairy cattle, including corn germ meal, corn bran, corn meal, and corn gluten feed. As in corn grain, the predominant protein in these by-products is zein, which is known to be low in Lys (Coleman and 
Larkins, 1999). Kelzer et al. (2010) characterized the AA profile of 7 corn by-products and observed that RUP Lys was below 3.5\% in all 7 feedstuffs. Therefore, it is not surprising when nutrition models predict that diets containing large concentrations of corn byproducts do not supply enough Lys to high-producing cows. It is also recognized that many lactation diets do not supply adequate Met; thus, Lys and Met have often been deemed first-limiting AA in lactation diets (Schwab et al., 1976; Schwab et al., 1992; NRC, 2001).

The objective of this study was to evaluate the effects of supplementing commercial rumen escape AA products in a diet that the NRC (2001) model predicted to be deficient in Lys and Met supply. The products used to provide the additional AA contained Lys embedded within Ca salts of FA (Megamine-L, Arm \& Hammer Animal Nutrition, Princeton, NJ) and the Met precursor isopropyl ester of 2-hydroxy-4-(methylthio) butanoic acid (HMBi; MetaSmart, Adisseo Inc., Antony, France). We hypothesized that providing additional essential AA with these products would increase milk protein production in lactating dairy cattle.

Experimental procedures were approved by the Institutional Animal Care and Use Committee at Kansas State University. Primiparous $(\mathrm{n}=33)$ and multiparous $(\mathrm{n}=63)$ Holstein cows $[186 \pm 51$ DIM (mean \pm SD)] from the Kansas State University Dairy Cattle Teaching and Research Facility were used in this production study. Cows were blocked by milk production, parity, and pregnancy status. Cows within each block were then randomly assigned to 1 of 8 identical pens with 12 freestalls in each pen. Cows were moved into pens on May 3, 2010, and the study began on May 10, 2010, allowing for a 1-wk adaptation period. During the adaption period, all pens received a common diet.

The study consisted of a single 28-d treatment period. During this period, pens (4/diet) were offered 1 of 2 diets that were formulated to differ in metabolizable AA supply (Table 1). Treatment diets were randomly assigned to pen. Cows were fed once daily at $110 \%$ of the expected intake. The amounts of feed delivered and refused were recorded on d 19, 20, 21, 26, 27, and 28 (3 times in each of the final $2 \mathrm{wk}$ ). Total mixed ration samples from both treatments were analyzed for DM on those days. Samples of all dietary ingredients were collected on d 19, 21, 26, and 28 and composited for wet chemistry analysis by Dairy One Forage Laboratory (Ithaca, NY).

Cows were milked 3 times daily in a milking parlor and milk yields were recorded at each milking. Milk samples were collected from every milking on each Monday, Wednesday, and Friday throughout the experiment. Samples were analyzed for concentrations of fat, true protein, lactose (B-2000 Infrared Analyzer;
Bentley Instruments, Chaska, MN), and urea nitrogen (MUN spectrophotometer, Bentley Instruments; Heart of America DHIA, Manhattan, KS). Energy-corrected milk yield was calculated as $0.327 \times$ milk yield +12.86 $\times$ fat yield $+7.65 \times$ protein yield (Dairy Record Management Systems, 2010).

The chemical composition of the feed ingredients, intake data, production data, and animal descriptors were all entered into 3 computer programs or models: Spartan Dairy Ration Evaluator 3.0 (Michigan State University, East Lansing, MI), which is based on the NRC (2001) model with some additional improvements developed at Michigan State University (East Lansing, MI); CPM-Dairy 3.0.10 from Cornell University (Ithaca, NY), University of Pennsylvania (Philadelphia, PA), and Miner Institute (Chazy, NY), which uses the Cornell Net Carbohydrate and Protein System (CNCPS) 5.0 (Fox et al., 2004); and Nutritional Dynamic System v3 (RUM\&M, Emilia, Italy), which uses the CNCPS 6.1 model. Models were used to determine the predicted supply of AA against model-specific requirements. For all 3 programs, a feed library was created so the nutrient profile of each dietary ingredient matched laboratory analyses. Megamine-L was assumed to be $16 \%$ digestible rumen bypass Lys on a DM basis, and HMBi was assumed to be $17 \%$ digestible rumen bypass Met on a DM basis.

A total of 95 of the 96 cows completed the study; 1 cow was removed from the study due to mastitis. Intake data for each pen was divided by the number of cows present in that pen on that day. All data were analyzed using the mixed procedure of SAS (version 9.2, SAS Institute Inc., Cary, NC). All models included the fixed effects of day, treatment, and day $\times$ treatment interaction and the random effect of pen. Repeated measures over time were modeled with a first-order autoregressive covariance structure; the subject was pen for intake data and cow within pen for milk production and component data. Denominator degrees of freedom were estimated by the Kenward-Roger method. Significance was declared at $P<0.05$ and tendencies at $0.05 \leq P$ $<0.10$.

In formulating experimental diets, the strategy was to feed a control diet that would be deficient in Lys and Met. As part of that strategy, the goal was to maintain large concentrations of corn by-products within diets. Therefore, the control diet (Table 1) contained 26.7\% wet corn gluten feed on a DM basis. Wet corn gluten feed has been reported to contain as little as $6.5 \%$ RUP (\% of CP; Kononoff et al., 2007), so a diet containing such a great quantity of wet corn gluten feed could exacerbate any MP deficiency. The treatment diet was similar to the control, with the primary differences being replacement of $190 \mathrm{~g} / \mathrm{cow}$ of the Ca salts of FA 
Table 1. Ingredient and nutrient compositions of diets fed to lactating Holstein cows

\begin{tabular}{|c|c|c|}
\hline \multirow[b]{2}{*}{ Item $(\%$ of $\mathrm{DM})$} & \multicolumn{2}{|c|}{ Dietary treatment } \\
\hline & Control & AA supplemented \\
\hline \multicolumn{3}{|l|}{ Ingredient } \\
\hline Corn silage & 23.4 & 23.4 \\
\hline $\mathrm{WCGF}^{1}$ & 26.7 & 26.6 \\
\hline Alfalfa hay & 18.5 & 18.7 \\
\hline Cottonseed & 5.4 & 5.3 \\
\hline Ground corn grain & 14.2 & 14.2 \\
\hline Ground milo & 2.7 & 2.7 \\
\hline Expeller soybean meal ${ }^{2}$ & 4.9 & 4.9 \\
\hline Fish meal, Menhaden & 0.3 & 0.3 \\
\hline Ca salts of long-chain $\mathrm{FA}^{3}$ & 0.7 & - \\
\hline Ca salts of FA-Lys matrix ${ }^{4}$ & - & 0.7 \\
\hline $\mathrm{HMBi}^{5}$ & - & 0.04 \\
\hline Micronutrient premix ${ }^{6}$ & 3.3 & 3.3 \\
\hline \multicolumn{3}{|l|}{ Nutrient } \\
\hline $\mathrm{DM}(\%$ as fed $)$ & 55.6 & 55.6 \\
\hline $\mathrm{CP}$ & 17.8 & 17.9 \\
\hline $\mathrm{NDF}$ & 33.3 & 32.9 \\
\hline Crude fat & 4.7 & 4.5 \\
\hline Starch & 24.0 & 23.5 \\
\hline $\mathrm{NFC}^{7}$ & 37.6 & 37.9 \\
\hline Ash & 6.9 & 6.8 \\
\hline $\mathrm{NE}_{\mathrm{L}}^{8}(\mathrm{Mcal} / \mathrm{kg})$ & 1.68 & 1.67 \\
\hline $\mathrm{Ca}$ & 0.83 & 0.79 \\
\hline $\mathrm{P}$ & 0.54 & 0.53 \\
\hline $\mathrm{Mg}$ & 0.35 & 0.33 \\
\hline $\mathrm{K}$ & 1.41 & 1.42 \\
\hline $\mathrm{Na}$ & 0.42 & 0.44 \\
\hline Net energy allowable milk $^{8}(\mathrm{~kg} / \mathrm{d})$ & 47.4 & 47.1 \\
\hline Metabolizable protein-allowable milk $^{8}(\mathrm{~kg} / \mathrm{d})$ & 45.6 & 45.9 \\
\hline \multicolumn{3}{|c|}{${ }^{1}$ WCGF = wet corn gluten feed, Sweet Bran (Cargill Inc., Blair, NE). } \\
\hline \multicolumn{3}{|c|}{${ }^{2}$ Soybest (Grain States Soya Inc., West Point, NE). } \\
\hline \multicolumn{3}{|c|}{${ }^{3}$ Megalac-R (Arm \& Hammer Animal Nutrition, Princeton, NJ). } \\
\hline \multirow{5}{*}{\multicolumn{3}{|c|}{$\begin{array}{l}{ }^{4} \text { Calcium salts of FA plus lysine monohydrochloride, Megamine-L (Arm \& Hammer Animal Nutrition). } \\
{ }^{5} \text { Isopropyl ester of } 2 \text {-hydroxy-4-methylthio butanoic acid, MetaSmart (Adisseo Inc., Antony, France). } \\
{ }^{6} \text { The premix consisted of } 41.6 \% \text { limestone, } 32.5 \% \text { sodium bicarbonate, } 6.50 \% \text { Diamond V XP (Diamond V, } \\
\text { Cedar Rapids, IA), } 5.40 \% \text { trace mineral salt, } 5.40 \% \text { magnesium oxide, } 5.20 \% \text { vitamin E premix, } 1.66 \% 4-p l e x \text {, } \\
0.93 \% \text { Se premix, } 0.36 \% \text { vitamin A premix, } 0.16 \% \text { vitamin D premix, } 0.05 \% \text { ethylenediamine dihydroiodide, } \\
\text { and } 0.21 \% \text { Rumensin } 80 \text { (Elanco Animal Health, Greenfield, IN). }\end{array}$}} \\
\hline & & \\
\hline & & \\
\hline & & \\
\hline & & \\
\hline \multicolumn{3}{|c|}{${ }^{7}$ Calculated as DM - (CP + NDF + ether extract + ash $)$} \\
\hline${ }^{8}$ Estimated according to NRC (2001) at actual & & \\
\hline
\end{tabular}

(Megalac-R, Arm \& Hammer Animal Nutrition) with a source of $\mathrm{Ca}$ salts of FA that was embedded with Lys (Megamine-L), and addition of $14 \mathrm{~g} / \mathrm{cow}$ of HMBi (MetaSmart). As expected, the predicted supplies of metabolizable Lys and Met were slightly elevated with AA supplementation (Table 2), whereas other nutrient concentrations remained similar across treatments (Table 1).

Model predictions for percent of MP and Lys-to-Met ratio are listed in Table 2. The NRC model predicted an inadequate ratio of Lys to Met (2.92), and these AA as a percentage of MP were less than NRC (2001) guidelines for maintenance and milk protein production (7.2 and $2.4 \%$ of MP for Lys and Met, respectively). Model predictions obtained through the NRC (2001) indicated negative Lys $(-8.1 \mathrm{~g})$ and Met $(-1 \mathrm{~g})$ bal- ances for the control cows; however, CNCPS 5.0 and 6.1 predicted positive balances for these AA (25.9 and 21.8 $\mathrm{g}$ for Lys, 14.7 and $18.9 \mathrm{~g}$ for Met, respectively). Amino acid supplementation using the commercial products led to a predicted positive Lys and Met balance by all 3 models.

Intake and production means for both groups are shown in Table 3 . Mean DMI was $26.6 \mathrm{~kg} / \mathrm{d}$ and mean milk yield was $40.1 \mathrm{~kg} / \mathrm{d}$, with means of $3.10 \%$ fat and $3.06 \%$ protein. No treatment effects were observed for any of the parameters measured. Milk protein yield, the variable of greatest interest, was numerically lower for the AA-supplemented diet compared with control (1.21 vs. $1.23 \pm 0.02 \mathrm{~kg} / \mathrm{d} ; P=0.54)$.

Results did not support the hypothesis that increasing the Lys and Met supply would increase production 
Table 2. Predicted metabolizable Lys and Met supplies and predicted metabolizable Lys-to-Met ratio by 3 different models

\begin{tabular}{|c|c|c|c|c|c|c|}
\hline \multirow[b]{2}{*}{ Item $^{1}$} & \multicolumn{3}{|c|}{ Control } & \multicolumn{3}{|c|}{ AA supplemented } \\
\hline & Lys & Met & Ratio $^{2}$ & Lys & Met & Ratio $^{2}$ \\
\hline \multicolumn{7}{|l|}{$\mathrm{g} / \mathrm{d}$} \\
\hline NRC (2001) & 191 & 65 & 2.92 & 206 & 67 & 3.07 \\
\hline CNCPS 5.0 & 181 & 64 & 2.84 & 197 & 66 & 2.99 \\
\hline CNCPS 6.1 & 165 & 62 & 2.66 & 194 & 67 & 2.89 \\
\hline \multicolumn{7}{|c|}{ Metabolizable protein (\%) } \\
\hline NRC (2001) & 6.3 & 2.2 & & 6.8 & 2.2 & \\
\hline CNCPS 5.0 & 6.1 & 2.1 & & 6.6 & 2.2 & \\
\hline CNCPS 6.1 & 5.3 & 2.0 & & 6.0 & 2.1 & \\
\hline
\end{tabular}

${ }^{1}$ CNCPS $=$ Cornell Net Carbohydrate and Protein System.

${ }^{2}$ Lysine-to-methionine calculated based on grams of predicted AA supply.

of cows fed a corn by-product-based diet. Several possible explanations exist for the lack of response. One possibility is that the products used to provide supplemental Met and Lys did not increase the metabolizable supply of these AA. Exposing this Lys source to TMR ingredients can cause up to $20 \%$ of Lys to be released from the protective matrix before being consumed by the cow (Ji et al., 2012). However, past research has indicated that the Lys source used in this study provides $70 \%$ protection from ruminal degradation at $3 \mathrm{~h}$ and $47 \%$ protection at $12 \mathrm{~h}$, suggesting effective postruminal delivery of Lys (Block et al., 2010; Zuccarello et al., 2011). For the HMBi, a calibration curve established by modeling the area under the curve response to increasing doses of Met indicates that approximately $50 \%$ of $\mathrm{HMBi}$ is absorbed through the rumen wall, and, thus, escapes ruminal degradation (Graulet et al., 2005). The efficacy of HMBi is further supported by production responses showing that HMBi supplementation increases milk protein when production appears to be limited by metabolizable Met supply (St-Pierre and Sylvester, 2005; Phipps et al., 2008; Chen et al., 2011). Although estimates of ruminal protection for these products may be imprecise, it is likely that at least some additional Lys and Met were absorbed.

A more likely reason why Lys and Met supplementation did not increase production is that another nutrient, or possibly mammary synthetic capacity, was firstlimiting in this scenario. Our study narrowly focused on Lys and Met because substantial research has supported the focus on a Lys and Met deficiency in diets similar to those fed in our study (Nichols et al., 1998; Wickersham et al., 2004; Vyas and Erdman, 2009; Patton, 2010), and infusion of Lys or Met has increased production in several dairy nutrition studies (Schwab et al., 1976; Pisulewski et al., 1996; Varvikko et al., 1999). Histidine has sometimes been identified as a limiting AA in dairy cattle diets, but the controlled research

Table 3. Effects of supplementing Lys embedded within $\mathrm{Ca}$ salts of $\mathrm{FA}^{1}$ and $\mathrm{HMBi}^{2}$ on performance of lactating Holstein cows

\begin{tabular}{|c|c|c|c|c|}
\hline \multirow[b]{2}{*}{ Item } & \multicolumn{2}{|c|}{ Treatment } & \multirow[b]{2}{*}{ SEM } & \multirow[b]{2}{*}{$P$-value } \\
\hline & Control & AA supplemented & & \\
\hline DMI (kg/d) & 26.4 & 26.7 & 0.49 & 0.65 \\
\hline \multicolumn{5}{|l|}{ Yield (kg/d) } \\
\hline Milk & 40.1 & 40.1 & 0.65 & 0.98 \\
\hline Milk fat & 1.22 & 1.25 & 0.03 & 0.59 \\
\hline Milk protein & 1.23 & 1.21 & 0.02 & 0.54 \\
\hline Milk lactose & 1.95 & 1.96 & 0.04 & 0.96 \\
\hline $\mathrm{ECM}^{3}$ & 38.2 & 38.5 & 0.69 & 0.81 \\
\hline Milk fat (\%) & 3.07 & 3.12 & 0.06 & 0.59 \\
\hline Milk protein $(\%)$ & 3.08 & 3.04 & 0.04 & 0.51 \\
\hline Milk lactose (\%) & 4.88 & 4.88 & 0.03 & 0.97 \\
\hline MUN (mg/dL) & 13.9 & 14.3 & 0.24 & 0.25 \\
\hline
\end{tabular}


showing this was conducted with diets containing large proportions of grass silages, barley, oats, and canola, instead of corn sources (Schwab et al., 2005). Corn grain contains almost no Trp (Coleman and Larkins, 1999), so diets with large amounts of corn silage and corn byproducts, such as the diets in the current study, could possibly be deficient in Trp. NRC (2001) also suggests that Phe and Ile are frequently limiting, behind Lys and Met, in corn-based diets. Energy intake could have also been limiting, but model predictions indicated a positive energy balance.

Hormonal signaling (Burgos et al., 2010) and energy status (Proud, 2007) of the mammary cells will also influence protein synthesis. It is possible that the fermentability of the carbohydrates in these diets triggered an insulin response (Grant et al., 1990), which led to greater efficiency of milk protein production, compensating for any marginal AA deficiency. We hypothesize this based on the low milk fat concentration observed $(\approx 3.1 \%)$ and on past results demonstrating that similar diets can induce milk fat depression if particle size is not carefully maintained (Bradford and Mullins, 2012). Given the low dietary fat concentrations $(<5 \%)$ in these diets, the milk fat depression was likely related to carbohydrate fermentability. In such a situation, a large proportion of the dietary NFC is fermented to produce propionate, which is a secretagogue of insulin (Harmon, 1992). An abundance of research has been published linking elevated insulin concentration to improved milk protein production (McGuire et al., 1995; Mackle et al., 1999; Molento et al., 2002). Blood samples were not collected in our study, so this hypothesis cannot be evaluated. We also recognize that the effects of AA supply on mammary intracellular signals promoting translation can be independent of insulin (Appuhamy et al., 2011), but this was observed in a media that was considerably deficient in AA supply ( $5 \%$ of normal AA supply). If AA were supplied at levels near the requirements, such as in our study, the response to elevated insulin and essential AA could be less independent; therefore, milk protein production responses would be smaller.

Focusing on AA as a proportion of MP was misleading in this study. The NRC model estimated an MP balance of $250 \mathrm{~g} / \mathrm{d}$ for the control diet, which allowed for a relatively high level of milk production to be supported with lower levels of AA as a percent of MP. For example, if MP had been supplied at exactly the required amount, $6.8 \%$ Lys may be necessary to meet a cow's requirement; but if MP is oversupplied by $10 \%$, then $6.2 \%$ Lys would provide the same amount of Lys and similarly meet the requirement. Not surprisingly, a meta-analysis examining 281 published diets indicated that neither Met nor Lys supply, expressed as a propor- tion of MP, was correlated with milk protein content (Patton et al., 2003).

It is also possible that the NRC model prediction, which was used to suggest a Lys limitation in the control diet, was imprecise. It would be unrealistic to expect perfect model predictions in these diets because most of the diets within the databases used to create these models did not contain high inclusion rates of nonforage fiber sources, and nonforage fiber sources alter the kinetics of digestion and passage rate (Firkins, 1997). Another concern is that models do not account for associative effects within diets, which is likely to be a major factor when substantial amounts of NFC are replaced by nonforage NDF (Beckman and Weiss, 2005).

Even if passage rate was estimated correctly, the Lys limitation could be related to an inaccurate prediction of metabolizable Lys supply. Schingoethe et al. (2009) pointed out that recoverable Lys content of distillers grains currently on the market is actually greater than the NRC (2001) suggests (3.15 vs. $2.24 \%$ of CP), which is likely due to improvements in the dry corn-milling process that minimizes heat damage. It is probable that similar progress has been made with wet corn milling, although surveys have not been conducted to validate this; regardless, database values should be used cautiously.

Feeding supplemental Lys embedded in a matrix of Ca salts of FA combined with an HMBi source did not affect performance and intake in diets containing large proportions of wet corn gluten feed. This is likely because the diet fed to control cows was either not deficient in Lys and Met, or the supplemental AA products used did not provide effective levels of ruminal escape AA. More information is needed for field nutritionists to effectively incorporate AA balancing when formulating diets with high levels of wet corn gluten feed.

\section{ACKNOWLEDGMENTS}

The authors express their appreciation to Mike Scheffel, Jamie Hermann, and all the undergraduate student workers (all at Kansas State University, Manhattan) who helped with the research trial. We also thank Arm \& Hammer Animal Nutrition for funding this work.

\section{REFERENCES}

Appuhamy, J. A., A. L. Bell, W. A. Nayananjalie, J. Escobar, and M. D. Hanigan. 2011. Essential amino acids regulate both initiation and elongation of mRNA translation independent of insulin in MAC-T cells and bovine mammary tissue slices. J. Nutr. 141:1209-1215.

Beckman, J. L., and W. P. Weiss. 2005. Nutrient digestibility of diets with different fiber to starch ratios when fed to lactating dairy cows. J. Dairy Sci. 88:1015-1023. 
Block, E., E. Evans, and N. Clark. 2010. Supplemental metabolizable lysine delivered with Megamine-L improves productive performance of lactating cows. J. Dairy Sci. 93(E-Suppl. 1):439-440. (Abstr.)

Bradford, B. J., and C. R. Mullins. 2012. Invited review: Strategies for promoting productivity and health of dairy cattle by feeding nonforage fiber sources. J. Dairy Sci. 95:4735-4746.

Burgos, S. A., M. Dai, and J. P. Cant. 2010. Nutrient availability and lactogenic hormones regulate mammary protein synthesis through the mammalian target of rapamycin signaling pathway. J. Dairy Sci. 93:153-161.

Chen, Z. H., G. A. Broderick, N. D. Luchini, B. K. Sloan, and E. Devillard. 2011. Effect of feeding different sources of rumen-protected methionine on milk production and N-utilization in lactating dairy cows. J. Dairy Sci. 94:1978-1988.

Coleman, C. E., and B. A. Larkins. 1999. The prolamins of maize. Pages 109-139 in Seed Proteins. P. R. Shewry and R. Casey, ed. Taylor \& Francis Publishers, New York, NY.

Dairy Herd Network. 2010. Amino acid balancing survey. Accessed Aug. 2, 2011. http://images.vancepublishing.com/pdfs/dairyherd/ Amino_Acid_Balancing_Survey_June_2010.pdf.

Dairy Record Management Systems. 2010. DHI glossary. Accessed Dec. 3, 2010. http://www.drms.org/PDF/materials/glossary.pdf.

Firkins, J. L. 1997. Effects of feeding nonforage fiber sources on site of fiber digestion. J. Dairy Sci. 80:1426-1437.

Fox, D. G., L. O. Tedeschi, T. P. Tylutki, J. B. Russell, M. E. Van Amburgh, L. E. Chase, A. N. Pell, and T. R. Overton. 2004. The Cornell Net Carbohydrate and Protein System model for evaluating herd nutrition and nutrient excretion. Anim. Feed Sci. Technol. 112:29-78.

Grant, R. J., V. F. Colenbrander, and D. R. Mertens. 1990. Milk fat depression in dairy cows: Role of silage particle size. J. Dairy Sci. 73:1834-1842.

Graulet, B., C. Richard, and J. C. Robert. 2005. Methionine availability in plasma of dairy cows supplemented with methionine hydroxy analog isopropyl ester. J. Dairy Sci. 88:3640-3649.

Harmon, D. L. 1992. Impact of nutrition on pancreatic exocrine and endocrine secretion in ruminants: A review. J. Anim. Sci. 70:1290-1301.

Ji, P., C. S. Ballard, R. E. Clark, B. M. Sweeney, and C. Kokko. 2012. Assessment of lysine released from rumen-protected lysine products exposed to high and low moisture TMR over 24 hours. J. Dairy Sci. 95(E-Suppl. 2):356. (Abstr.)

Kelzer, J. M., P. J. Kononoff, L. O. Tedeschi, T. C. Jenkins, K. Karges, and M. L. Gibson. 2010. Evaluation of protein fractionation and ruminal and intestinal digestibility of corn milling co-products. J. Dairy Sci. 93:2803-2815.

Kononoff, P. J., S. K. Ivan, and T. J. Klopfenstein. 2007. Estimation of the proportion of feed protein digested in the small intestine of cattle consuming wet corn gluten feed. J. Dairy Sci. 90:2377-2385.

Leonardi, C., M. Stevenson, and L. E. Armentano. 2003. Effect of two levels of crude protein and methionine supplementation on performance of dairy cows. J. Dairy Sci. 86:4033-4042.

Mackle, T. R., D. A. Dwyer, K. L. Ingvartsen, P. Y. Chouinard, J. M. Lynch, D. M. Barbano, and D. E. Bauman. 1999. Effects of insulin and amino acids on milk protein concentration and yield from dairy cows. J. Dairy Sci. 82:1512-1524.

McGuire, M. A., J. M. Griinari, D. A. Dwyer, and D. E. Bauman. 1995. Role of insulin in the regulation of mammary synthesis of fat and protein. J. Dairy Sci. 78:816-824.

Molento, C. F. M., E. Block, R. I. Cue, and D. Petitclerc. 2002. Effects of insulin, recombinant bovine somatotropin, and their interaction on insulin-like growth factor-I secretion and milk protein production in dairy cows. J. Dairy Sci. 85:738-747.

NRC (National Research Council). 2001. Nutrient Requirements of Dairy Cattle. 7th rev. ed. Natl. Acad. Sci., Washington, DC.
Nichols, J. R., D. J. Schingoethe, H. A. Maiga, M. J. Brouk, and M. S. Piepenbrink. 1998. Evaluation of corn distillers grains and ruminally protected lysine and methionine for lactating dairy cows. J. Dairy Sci. 81:482-491.

Noftsger, S., and N. R. St Pierre. 2003. Supplementation of methionine and selection of highly digestible rumen undegradable protein to improve nitrogen efficiency for milk production. J. Dairy Sci. 86:958-969.

Patton, R. A. 2010. Effect of rumen-protected methionine on feed intake, milk production, true milk protein concentration, and true milk protein yield, and the factors that influence these effects: A meta-analysis. J. Dairy Sci. 93:2105-2118.

Patton, R. A., M. J. Stevenson, and A. J. Duffield. 2003. Relation of arterial concentration of lysine and methionine to milk and milk protein production: A twenty-year literature review. J. Dairy Sci. 86(E Suppl. 1):275. (Abstr.)

Phipps, R. H., C. K. Reynolds, D. I. Givens, A. K. Jones, P. Geraert, E. Devillard, and R. Bennett. 2008. Short communication: Effects of 2-hydroxy-4-(methylthio) butanoic acid isopropyl ester on milk production and composition of lactating Holstein dairy cows. J. Dairy Sci. 91:4002-4005.

Pisulewski, P. M., H. Rulquin, J. L. Peyraud, and R. Verite. 1996. Lactational and systemic responses of dairy cows to postruminal infusions of increasing amounts of methionine. J. Dairy Sci. 79:1781-1791.

Proud, C. G. 2007. Signalling to translation: How signal transduction pathways control the protein synthetic machinery. Biochem. J. 403:217-234.

Schingoethe, D. J., K. F. Kalscheur, A. R. Hippen, and A. D. Garcia. 2009. Invited review: The use of distillers products in dairy cattle diets. J. Dairy Sci. 92:5802-5813.

Schwab, C. G. 2010. Balancing diets for amino acids: Nutritional, environmental and financial implications. Pages 1-13 in Proc. TriState Dairy Nutr. Conf., Fort Wayne, IN. The Ohio State University, Columbus.

Schwab, C. G., C. K. Bozak, N. L. Whitehouse, and M. M. Mesbah. 1992. Amino acid limitation and flow to duodenum at four stages of lactation. 1. Sequence of lysine and methionine limitation. J. Dairy Sci. 75:3486-3502.

Schwab, C. G., P. Huhtanen, C. W. Hunt, and T. Hvelplund. 2005. Nitrogen requirements of cattle. Pages 13-70 in Nitrogen and Phosphorus Nutrition of Cattle: Reducing the Environmental Impact of Cattle Operations. A. N. Hristov and E. Pfeffer, ed. CABI Publishing, Cambridge, MA.

Schwab, C. G., L. D. Satter, and B. Clay. 1976. Response to lactating dairy cows to abomasal infusion of amino acids. J. Dairy Sci. 59:1254-1270.

St-Pierre, N. R., and J. T. Sylvester. 2005. Effects of 2-hydroxy4-(methylthio) butanoic acid (HMB) and its isopropyl ester on milk production and composition by Holstein cows. J. Dairy Sci. 88:2487-2497.

Varvikko, T., A. Vanhatalo, T. Jalava, and P. Huhtanen. 1999. Lactation and metabolic responses to graded abomasal doses of methionine and lysine in cows fed grass silage diets. J. Dairy Sci. $82: 2659-2673$.

Vyas, D., and R. A. Erdman. 2009. Meta-analysis of milk protein yield responses to lysine and methionine supplementation. J. Dairy Sci. 92:5011-5018.

Wickersham, E. E., J. E. Shirley, E. C. Titgemeyer, M. J. Brouk, J. M. DeFrain, A. F. Park, D. E. Johnson, and R. T. Ethington. 2004. Response of lactating dairy cows to diets containing wet corn gluten feed or a raw soybean hull-corn steep liquor pellet. J. Dairy Sci. 87:3899-3911.

Zuccarello, W. J., E. Block, E. Roman, Z. Sek, and K. R. Cummings, inventors. 2011. Ruminant feedstock dietary supplement. Church \& Dwight Co. Inc., assignee. US Pat. No. 7,939,117. 